\title{
Relationship of Psychological Morbidity and Quality of Life in Professional Females
}

\author{
Hemantha Perera, Supipi Karunanayake, Pubudu de Silva
}

\begin{abstract}
During peri and menopause, a variety of psychological issues crop up and the most likely ones are depression, burnout, alcohol abuse and chronic fatigue. The aim of this study was to describe the prevalence of psychological disturbances in female health workers and female media personnel, and it was observed that, health workers, majority were anxious and depressed 51 years and above, compared to the media staff, where anxiety was mainly noticed between 41 and 50 years, and depression was common in less than 40 years.
\end{abstract}

Keywords: Depression, Anxiety, Media staff, Health workers.

How to cite this article: Perera $H$, Karunanayake S, de Silva P. R elationship of P sychological Morbidity and Q uality of Life in Professional Females. J South Asian Feder Menopause Soc 2013;1(1):24-26.

\section{Source of support $\mathrm{Nil}$}

Conflict of interest: None declared

\section{INTRODUCTION}

Work and family are the two domains from which most adults derive satisfaction in life; equally, they are the common sources of stressful experiences. The implications of work-related stress include the effects on worker satisfaction and productivity, their mental and physical health, absenteeism and its economic cost, the wider impact on family function and finally, the potential for employer liability. While depression is the most likely adverse psychological outcome, the range of other possible 'psychological' problems include 'burnout,' alcohol abuse, unexplained physical symptoms, 'absenteeism,' chronic fatigue and accidents, sick building syndrome and repetitive strain injury. ${ }^{1}$

In white-collar workers, there have been several large prospective studies. In a 4-year Finnish study, ${ }^{2}$ records linkage was used to access psychiatric morbidity data (suicides, hospitalization, prescription of psychotropic drugs). Interpersonal conflict at work predicted 'physiciandiagnosed' psychiatric morbidity even after controlling social class, prior health and prior 'mental instability/ stress'.2 In the impressive Whitehall II study, ${ }^{3-9}$ psychological morbidity was predicted both by poor work social supports and by high job demands. ${ }^{3}$

The nature of the speciality and the duration of professional experience influences risk of morbidity in doctors. For instance, in junior doctors ${ }^{10}$ low autonomy predicted psychological morbidity, while work demands were most predictive in older doctors. In relation to medical specialities for instance, work-related stress and specifically, 'Iow task - role clarity' predicted later depression in emergency medicine residents, ${ }^{11}$ while in general practitioners (GPs), ${ }^{12}$ routine work administration, job demands, interference with family and interruptions with work, predicted their negative mental well being.

Health care workers generally have psychological morbidity rates higher than the general population; in a large $\mathrm{N}$ ational $\mathrm{H}$ ealth Scheme(N HS) samplein the UK, therelative risk of disorder was 1.5 and was most marked in direct care staff and women in particular. ${ }^{13}$ In nurses, ${ }^{14}$ ' burnout-related absenteeism' was predicted by 'ambiguity about authority' and perceived lack of social support at work; this study was, however, limited by a low $43 \%$ response rate. In another sample of nurses, ${ }^{15}$ psychological well being was predicted by the congruence of work status (full- or part-time) with the desire for that degree of employment.

Thus, while different occupational groups may differ in the nature of their work environments, the 'social environment' (usually conflict in relationships or poor social support) seems to predict depressed mood or burnout in most occupational groups. A Iso reasonably consistent as a predictor are 'client-related' stressors in the caring professions. The objective of this study is to describe the prevalence of psychological disturbances in female health workers and female media personnel.

\section{METHODS}

This was a cross-sectional descriptive study conducted among 151 health care workers and 71 media personnel. A pretested self-administered questionnaire of a language of their preference was given to the study participants. The questionnaire required the participants to answer the questions on the demographic details, socioeconomic status and to complete two validated tool namely Center for Epidemiological Study from Depression (CES-R) to assess depression and hospital anxiety and depression scale (HADS), to assess anxiety and depression and U tian quality of life scale (UQOL) to assess quality of life. In both scales, 1 to 7 was taken as normal 8 to 12 as intermediate and above 13 was taken as suggestive of depression or anxiety.

The data was collected from M ay 2011 to September 2011. During the study period all medical officers and nursing officers present in the wards of Sri J ayewardenepura 
General Hospital participated in the study, while those who were present in three television stations, five newspaper press and four radio stations were included.

\section{RESULTS}

A mong thestudy participants of Sri J ayew ardenepura General Hospital, therewere 60 medical officers, 68 nursing officers, one orderly staff member, 17 paramedical staff and three clerical staff participated in thestudy. A mong thosefrom the media, $49(69 \%)$ werefrom thegovernmentinstitutions, while $22(31 \%)$ were from the private institutions. There were 39 television stations, 24 from new spapers and eight from radio stations. The Table 1 describes the distribution of the demographic detailsand psychological disorders of thestudy participants.

The Table 2 describes the distribution of the psychological disorders by selected demographic characteristics.

A mong the study participants from Sri J ayewardenepura General Hospital, majority were in the age category of 18 to 30 years, while it was 51 to 60 years among the media staff. In both the groups, majority were Sinhalese in ethnicity and were married. A mong the health care staff, majority had passed either ordinary level or advanced level exam, compared with the media staff where majority has educated only up to grade 5 to 10 . B oth the staff groups had mainly a monthly family income of ₹ 25,000 to 50,000 .

A mong those from the health staff, $125(82.8 \%)$ had anxiety, while 75 (49.7\%) were depressed. A mong the media staff, $55(77.5 \%)$ had anxiety and $42(59.2 \%)$ were depressed. In the health care staff, majority who were anxious and depressed were 51 years and above, compared to the media staff where anxiety was mainly noticed between 41 and 50 years and depression was common in less than 40 years.

In both groups married as well as single participants were equally anxious, while married participants were depressed than the single. Considering the level of education, in the health care group majority, who were anxious had passed either ordinary or advanced level examination, while majority who were depressed were educated above advanced level. In the media staff those who had passed ordinary or advanced level examination showed highest percentage of having anxiety or depression.

Table 1: Demographic characteristics and psychological disorders

\begin{tabular}{|c|c|c|c|c|}
\hline & \multicolumn{2}{|c|}{ Health care staff } & \multicolumn{2}{|c|}{ Media staff } \\
\hline & Number & Percentage & Number & Percentage \\
\hline \multicolumn{5}{|l|}{ Age categories (years) } \\
\hline 18 to 30 & 81 & 55.5 & 09 & 12.7 \\
\hline 31 to 40 & 23 & 15.8 & 12 & 16.9 \\
\hline 41 to 50 & 10 & 06.8 & 21 & 29.6 \\
\hline 51 to 60 & 32 & 21.9 & 27 & 38.0 \\
\hline 61 to 70 & 00 & 00.0 & 02 & 02.8 \\
\hline Missing & 05 & - & 00 & - \\
\hline \multicolumn{5}{|l|}{ Ethnicity } \\
\hline Sinhalese & 147 & 97.4 & 68 & 95.8 \\
\hline Tamil & 04 & 02.6 & 00 & 00.0 \\
\hline Muslim & 00 & 00.0 & 03 & 04.2 \\
\hline Missing & 00 & - & 00 & - \\
\hline \multicolumn{5}{|l|}{ Marital status } \\
\hline Married & 85 & 56.3 & 54 & 76.1 \\
\hline Single & 66 & 43.7 & 09 & 12.7 \\
\hline Widowed & 00 & 00.0 & 04 & 05.6 \\
\hline Divorced/separated & 00 & 00.0 & 04 & 05.6 \\
\hline Missing & 00 & - & 00 & - \\
\hline \multicolumn{5}{|l|}{ Level of education } \\
\hline Less than grade 5 & 01 & 0.7 & 14 & 19.7 \\
\hline Grade $5-10$ & 04 & 2.7 & 43 & 60.6 \\
\hline Ordinary level to advanced level & 96 & 63.6 & 13 & 18.3 \\
\hline Advanced level and above & 50 & 33.2 & 01 & 01.4 \\
\hline Missing & 00 & - & 00 & - \\
\hline \multicolumn{5}{|l|}{ Monthly family income } \\
\hline Less than ₹ 25,000 & 04 & 03.3 & 08 & 12.1 \\
\hline$₹ 25,001-50,000$ & 31 & 25.2 & 15 & 22.7 \\
\hline$₹ 50,001-75,000$ & 30 & 19.9 & 28 & 42.4 \\
\hline$₹ 75,001-100,000$ & 23 & 15.2 & 14 & 21.2 \\
\hline More than ₹ 100,001 & 35 & 23.2 & 01 & 01.5 \\
\hline Missing & 28 & - & 05 & 5.2 \\
\hline \multicolumn{5}{|l|}{ Psychological disorders } \\
\hline Anxiety & 125 & 82.8 & 55 & 77.5 \\
\hline Poor UQO level & 139 & 92.1 & 15 & 21.1 \\
\hline Depressed & 75 & 49.7 & 42 & 59.2 \\
\hline Total & 151 & 100 & 494 & 100 \\
\hline
\end{tabular}


Table 2: The distribution of the psychological disorders by selected demographic characteristics

\begin{tabular}{|c|c|c|c|c|c|c|}
\hline & \multicolumn{3}{|c|}{ Healthcare staff $(\mathrm{n}=151)$} & \multicolumn{3}{|c|}{ Media staff } \\
\hline & Anxious & Depressed & Poor UQO & Anxious & Depressed & Poor UQO \\
\hline \multicolumn{7}{|l|}{ Age categories } \\
\hline Less than 40 years & $82(78.8 \%)$ & $38(48.1 \%)$ & $11(10.6 \%)$ & $17(81.0 \%)$ & $15(93.8 \%)$ & $05(23.8 \%)$ \\
\hline $41-50$ years & $09(90.0 \%)$ & $05(55.6 \%)$ & $01(10.0 \%)$ & $18(85.7 \%)$ & $09(60.0 \%)$ & $04(19.0 \%)$ \\
\hline 51 and above & $30(93.8 \%)$ & $29(90.6 \%)$ & $00(00.0 \%)$ & $20(69.0 \%)$ & $18(90.0 \%)$ & $06(20.7 \%)$ \\
\hline Missing & 05 & 05 & 05 & 00 & 00 & 00 \\
\hline \multicolumn{7}{|l|}{ Marital status } \\
\hline Married & $70(82.4 \%)$ & $55(70.5 \%)$ & $04(04.7 \%)$ & $42(77.8 \%)$ & $31(81.6 \%)$ & $14(25.9 \%)$ \\
\hline Single & $55(83.3 \%)$ & $20(42.6 \%)$ & $08(12.1 \%)$ & $07(77.8 \%)$ & $07(87.5 \%)$ & $01(11.1 \%)$ \\
\hline Missing & 05 & 05 & 05 & 00 & 00 & 00 \\
\hline \multicolumn{7}{|l|}{ Level of education } \\
\hline Below ordinary level & $04(80.0 \%)$ & $01(25.0 \%)$ & $00(00.0 \%)$ & $44(77.2 \%)$ & $30(76.9 \%)$ & $13(22.8 \%)$ \\
\hline $\begin{array}{l}\text { Ordinary level to } \\
\text { advance level }\end{array}$ & $85(88.5 \%)$ & $43(55.1 \%)$ & $12(12.5 \%)$ & $10(76.9 \%)$ & $11(100 \%)$ & $02(15.4 \%)$ \\
\hline Above advance level & $36(72.0 \%)$ & $31(68.9 \%)$ & $00(00.0 \%)$ & $01(100 \%)$ & $01(100 \%)$ & $00(00.0 \%)$ \\
\hline Missing & 00 & 00 & 00 & 00 & 00 & 00 \\
\hline \multicolumn{7}{|l|}{ Monthly family income (₹) } \\
\hline Below 50,000 & $31(88.6 \%)$ & $06(25.0 \%)$ & $07(20.0 \%)$ & $18(78.3 \%)$ & $09(64.3 \%)$ & $09(39.1 \%)$ \\
\hline $50,000-100,000$ & $47(88.7 \%)$ & $34(73.9 \%)$ & $04(07.5 \%)$ & $33(78.6 \%)$ & $30(88.2 \%)$ & $05(11.9 \%)$ \\
\hline Above 100,000 & $24(68.6 \%)$ & $24(72.7 \%)$ & $01(02.9 \%)$ & $01(100 \%)$ & $00(00.0 \%)$ & $00(00.0 \%)$ \\
\hline Missing & 28 & 28 & 28 & 05 & 05 & 05 \\
\hline
\end{tabular}

A mong the health carestaff thosew ho had monthly family income less than $₹ 50,000$ as well as those who had between 50,000 and 100,000 equally showed anxiety, while depression was mainly noticed in those who had ₹ 50,000 to $1,00,000$ monthly family income. In the media staff those who had monthly family income of ₹ 50,000 to $1,00,000$ showed highestpercentages for anxiety as well as depression.

\section{REFERENCES}

1. Hotopf M, W essely S. Stress in the workplace: Unfinished business. J Psychosom Res 1997;43(1):1-6.

2. Romanov K, Appelberg K, Honkasalo ML, Koskenvuo M. Recent interpersonal conflict at work and psychiatric morbidity: A prospective study of 15,530 employees aged 24 to 64 . J Psychosom Res 1996;40(2):169-76.

3. Stansfeld SA, Fuhrer R, H ead J, Ferrier J, Shipley M. W ork and psychiatric disorder in the Whitehall II study. J Psychosom Res 1997;43(1):73-81

4. Stanfield SA, North FM, W hite I, M armot M G. W ork characteristics and psychiatric disorder in civil servants in London. J Epidemiol Community Health 1995;49(1):48-53.

5. Stansfeld SA, Bosma H, Hemingway $H, M$ armot M G. Psychosocial work characteristics and social support as predictors of SF-36 health functioning: The W hitehall II study. Psychosom M ed 1998;60(3):247-57.

6. Stansfeld SA, Head J, M armot M G. Explaining social class differences in depression and well-being. Soc Psychiatry Psychiatr Epidemiol 1998;33(1):1-9.

7. Ferrie JE, Shipley MJ, M armot M G, Stansfeld SA, Smith GD. A $n$ uncertain future: The health effects of threats to employment security in white-collar men and women. A m J Public Health 1998;88(7):1030-36.

8. Ferrie JE, Shipley MJ, M armot M G, Stansfeld S, Smith GD. The health effects of major organisational change and job insecurity. Soc Sci M ed 1998;46(2):243-54.

9. Ferrie JE, Shipley M J, M armot M G, Stansfeld SA, Smith GD. Health effects of anticipation of job change and non employment:
Longitudinal data from the Whitehall II study. BMJ 1995; 311(7015):1264-69.

10. K apur N, B orrill C, Stride C. Psychological morbidity and job satisfaction in hospital consultants and junior house officers: Multicentre, cross-sectional survey. BMJ 1998;317:511-22.

11. Revicki DA, W hitley TW, Gallery M E, Allison EJ. The impact of work environment characteristics on work-related stress and depression in emergency medical residents: A longitudinal study. J Community A ppl Soc Psychol 1993;3(4):273-84.

12. Rout U, Cooper CL, R out JK. J ob stress among B ritish general practitioners: Predictors of job dissatisfaction and mental illhealth. Stress M ed 1996;12(3):155-66.

13. W all TD, B olden RI, B orrell CS, Carter AJ, Golya DA, Hardy $G E$, et al. Minor psychiatric disorder in NHS trust staff: Occupational and gender differences. $\mathrm{Br} J$ Psychiatry 1997;171:519-23.

14. Firth $\mathrm{H}$, Britton $\mathrm{P}$. 'Burnout' absence and turnover amongst British nursing staff. J Occup Psychol 1989;62(1):55-59.

15. Burke RJ, Greenglass ER. W ork status congruence work outcomes and psychological well-being. Stress M ed 2000;16(2): 91-99.

\section{ABOUT THE AUTHORS}

\section{Hemantha Perera}

Consultant, Department of Obstetric and Gynecology, Sri Jayawardenapura General Hospital, Sri Lanka

Correspondence Address No 112, Model Farm Road, Colombo 08 Sri L anka, Tel/Fax: +94112699211, e-mail: hemanthawasantha@gmail.com

\section{Supipi Karunanayake}

Registrar, Department of Psychiatry, Colombo North Teaching Hospital, Ragama, Sri Lanka

\section{Pubudu De Silva}

Senior Registrar, Department of Community M edicine, National Intensive Care Surveillance, M inistry of H ealth, Sri Lanka 